\title{
ОБ ЭКОНОМИЧЕСКОЙ ОЦЕНКЕ КАРБОНАТНЫХ ПОРОД ДЛЯ ПРОИЗВОДСТВА ЩЕБНЯ В ЭСТОНСКОЙ ССР
}

\author{
Aada TEEDUMAE. KILLUSTIKUKS SOBIVATE KARBONAATKIVIMITE MAJANDUSLIKUST \\ HINNANGUST EESTI NSV-S \\ Aada TEEDUMÄE. ABOUT AN ECONOMIC ESTIMATION OF THE CARBONATE ROCKS SUITABLE \\ FOR CRUSHED AGGREGATES IN THE ESTONIAN SSR
}

Проблема экономической оценки запасов полезных ископаемых в настоящее время крайне актуальна. Практика социалистического хозяйствования настоятельно требует введения денежной оценки природных богатств. Однако показатель, по отношению к которому вычисляется ожидаемый потенциальный доход от эксплуатации запасов, т. е. дается экономическая оценка разведанных запасов, остается пока дискуссионным.

На сегодняшний день народнохозяйственный эффект от использования запасов карбонатных пород Эстонии можно определить лишь через соответствующие оптовые цены - единственный конкретный показатель, отражающий общественно-оправданные пределы затрат на производство сырья для строительных материалов.

Приведенная на базисный год разница между ожидаемым доходом от реализации продукции по оптовым ценам и теми затратами, которые в разные годы идут на геологоразведочные, горнокапитальные и эксплуатационные расходы (вплоть до исчерпания запасов), представляет собой «потенциальную актуализированную оценку запасов месторождения» (Хабихт, 1975).

Месторождениям, включенным в перспективный план развития отрасли горной промышленности, можно дать и «плановую актуализированную оценку» (Хабихт, 1975). Эта оценка, будучи высчитана принципиально тем же методом, что и потенциальная, определяет тот эффект, который обеспечивает использование запасов в объемах и сроках перспективного плана.

В целях получения первых конкретных представлений об эффективности использования карбонатных пород Эстонии автором был определен суммарный ожидаемый народнохозяйственный эффект (плановая актуализированная оценка) от использования их для производства щебня в ЭССР на $1975-1995$ гг.

Расчеты были произведены по четырем основным месторождениям Вяо, Падизе Паэмурруд, Маарду и Кунда-Тоолсе, суммарная продукция которых в настоящее время составляет более $80 \%$, а с 1981 г. превысит $90 \%$ от общереспубликанской. 
Полученная разница между ожидаемым доходом от реализации щебня по оптовым ценам и горнокапитальными и эксплуатационными затратами (суммарный эффект) была дисконтирована во времени на базисный 1975 г. Результат оказался отрицательным - около 2 млн. руб. актуализированного убытка.

Для контроля и выяснения причин получения отрицательной оценки расчет был повторен в предположении, что в горногеологических условиях месторождений карбонатных пород Северной Әстонии потребуется ввести в эксплуатацию новый типовой щебеночный завод производительностью 650 тыс. $M^{3}$ в год. Продолжительность периода для оценки была принята равной 30 годам - что является сроком работы завода без дополнительных капитальных вложений. Выяснилось, что результат оценки, дисконтированный на год начала строительства, также отрицателен около 3 млн. руб. актуализированного убытка.

Следовательно, в средних природных условиях Эстонии актуализированная оценка новых запасов карбонатных пород для производства щебня отрицательна.

Анализ причин отрицательных значений экономической оценки приводит к выводу, что главная из них - необоснованно низкие оптовые цены, не обеспечивающие необходимую для воспроизводства норму рентабельности (отношения суммы прибыли к стоимости производственных фондов), и слабая дифференциация цен по качеству. Последнее не стимулирует ни производителей повышать качество продукции (путем избирательного дробления, промывки), ни потребителей использовать щебень строго по назначению и в конечном счете порождает крупные недостатки в рациональном его использовании.

Действующие в настоящее время оптовые цены на щебень необходимо пересмотреть. Их совершенствование должно быть направлено по пути более полного учета 1) качества продукции, 2) фондоемкости подотрасли и 3) затрат на геологоразведочные работы.

Только после установления новых оптовых цен можно будет подсчитать тот ущерб, который приносят народному хозяйству нецелесообразное использование природных ресурсов и нарушение принципов полного и безотходного использования полезных ископаемых.

\section{Л ИТЕРАТУ Р А}

Х а б и х т К. 1975. Актуализированные экономические оценки запасов месторождений полезных ископаемых. В сб.: Научная конференция «Оценка и использование природных ресурсов и размещение производительных сил в Прибалтике», т. 1. Вильнюс. 4/XII 1975 